\title{
Trial by media, deceased defendants and the victim as a commodity
}

\begin{abstract}
The aim of this article is to assess the dynamic between the media, the public, victims and deceased offenders. Taking the recent events concerning Jimmy Savile in the UK and Rehavam Ze'evi in Israel as case studies, the article attempts to make sense of a rather complex social relationship. The article questions the social usefulness of aggressive journalism; it submits that the relationship between the mass media and the public is responsible for the reproduction of violence and the commodification of the victim.
\end{abstract}

Keywords: jimmy savile, rehavam ze'evi, sexual abuse, commodification of the victim, citizen journalism, ideal victim
Volume 6 Issue 6 - 2018

\author{
Susanna Menis \\ School of Law, Birkbeck University of London, London
}

Correspondence: School of Law, Birkbeck University of London, Malet Street, London WCIE 7HX,

Emails.manis@bbk.ac.uk

Received: February 02, 2018 | Published: November 28, 2018

\section{Introduction}

It is undeniable that mass-media has bridged the gap between time and space, presenting us with fresh and live information throughout the day, any day. Mass-media has democratised news accessibility and entertainment. Significantly however, the media facilitation of social solidarity through the social construction of the acts and/or events is artificial and dependant on the media's agenda, thus, it can go as far as reinforcing stereotypes and the labelling of individuals. ${ }^{1}$ Moreover, the media's drive for profit, contributes to the process of the comodification of crime whilst it clashes 'with the democratic ideals of liberal theory'. ${ }^{2}$ The aim of this article is to assess the dynamic between the media, the public, victims and deceased offenders by drawing upon two recent exposés, the one on Jimmy Savile in the UK and the one on Rehavam Ze'evi in Israel. The submission of this article is that the alleged victims in these two cases have been transformed into commodities. By drawing upon Green's ${ }^{3}$ theorisation of this dynamic, it is argued that the public and the media accompanied by the process of culturalisaton of the victim contribute to the reproduction of violence. The article opens with a short description of the public roles covered by Jimmy Savile and Rehavam Ze'evi; then an examination of each of the three factors required for the comodification of the victim will follow. First, the 'currency' will be assessed. According to Green ${ }^{3}$ the currency stands for the victim's vulnerability to harm. Here, the culturalisation of the victim and the concept of the ideal victim will be addressed. It is submitted that the social condemnation related to Jimmy Savile and Rehavam Ze'evi has less to do with the social re-construction of their transgression and more with the social re-construction of the ideal victim. Next, the analysis will turn to consider the factor of 'demand'; for Green ${ }^{3}$ this stands for demand for security subsequent to the fear of crime. However, this article takes a wider interpretation of 'demand' by drawing upon Presdee, ${ }^{4}$ understanding it as a demand for entertainment. Finally, the last factor responsible for the commodification of the victim will be considered, that is, the 'supply'. ${ }^{3}$ The assessment here will look into the notion of scandals as profitable news value and their artificial construction by the media in the context of the market place.

\section{Jimmy savile and rehavam ze'evi}

Jimmy Savile ${ }^{5}$ was an English DJ, television and radio presenter, as well as a prominent charity fundraiser. Although Savile presented and hosted a number of radio and TV shows, many will recognise him from the show Jim'll Fix It $t^{6}$ and the music chart show Top of the Pops. Following his public and charitable engagement he received a number of awards, including an Order of the British Empire in 1971 and a knighthood in 1990. Significantly, Savile volunteered in and raised money for a number of children hospitals' wards. ${ }^{7}$ A number of sporadic allegations of child abuse were made against him throughout his public career, from the early 1960s up to 2008; however, although at times a police investigation might have followed, there were never sufficient evidence to bring any charges. Savile himself started legal proceeding at least twice against different tabloids for linking him with these accusations. ${ }^{8}$ After his death in 2011 at the age of 84 two television documentaries were aired in 2012 and in 2016. Both documentaries recounted reconstructed stories of hundreds of sexual assaults. Fully engaging with many of the alleged Savile's victims and in the inevitable absence of a counter-story, Jimmy Savile was declared by the media as a predatory sex offender. An extensive police inquiry carried alongside an independent review by the former High Court Judge Dame Janet Smith confirmed the allegations, at least as far as the victims were concern. Having more than just the birth year in common, Rehavam Ze'evi' similarly to Jimmy Savile, was a well known public figure. Nicknamed 'gandhi', Ze'evi was a general in the Israel Defence Forces, a politician and cabinet minister. He was born in Jerusalem under what was then the British Palestine Mandate, and later joined the Palmach organisation who plaid a central role in the fight for Israeli independence. His extreme political approach to the Gaza question was cut short when in 2001 he was killed by members of the Popular Front for the Liberation of Palestine. ${ }^{10}$ After his death and despite his controversial political views, Ze'evi became an Israeli historical hero, where his life was integrated in the school curriculum and roads were named after him. Fifteen years after his death, a television documentary was aired, where a number of allegations such as conspiring with mafia bosses, bullying, violent and intimidating behaviour, as well as rape and sexual assaults- all these were threatening the reputation of who was considered until then a national icon. ${ }^{11}$

\section{The currency}

On the $11^{\text {th }}$ April 2016 the British Broadcasting Company (BBC) released to the British public the documentary Abused: The Untold Story. The documentary featured the stories of a number of Jimmy 
Savile's victims, explained through their experiences and emotions. However, the victims' silence had already been broken in 2012, with another documentary aired by the Independent Television (ITV), where shaky and shy victims revealed for the first time the unsettling reality that the TV and radio presenter Jimmy Savile was, rather than a 'national treasure', a sexual predator. Accidentally, on the $14^{\text {th }}$ April 2016 Channel two Keshet released to the Israeli public the documentary Gandhi- The true story behind the Myth. This documentary revealed the unsettling reality that Rehavam Ze'evi, considered until than a 'national hero', was in fact a frequent sexual harasser. As in the BBC documentary, the Israeli victims came forward unsealing a longlasting silence. These two cases have several features in common. Apart from the fact that both concern sexual offences, most of the victims have been carrying this personal secret since late 1960s, only coming forward after the deaths of both perpetrators. The cases have another feature in common, namely the role and involvement of the media in the presentation and investigation of the stories to the public. The stories of Savile and Ze'evi could not illustrate better the significant role that the media has as a watchdog or whistle-blower, ${ }^{12}$ thus serving public's interest by keeping it informed. It might therefore appear odd to propose, as argued by Presdee ${ }^{4}$ that the media, the police and the public have been 'partners' to the process of these crimes as much as the actual perpetrators. We could go as far as suggesting that these parties have had an important share in the reproduction of brutality within the wider context of what cultural criminology has termed as the commodification of crime. ${ }^{4}$ The submission here is that not only the deceased Savile and Ze'evi have been transformed into cultural entertainers, but also, that the victims themselves have been turned into commodities, and highly profitable one. The concept of the victim as a 'commodity' draws upon Green's (2007: 110) three interacting factors: the currency, the demand and the supply. These will be discussed consecutively against the respective stories of Savile and Ze'evi. The victims of the Savile and Ze'evi cases were approached by the media, and this is how they became public. And it is perhaps because of such a high level of exposure, not merely in the newspapers but on the screen, that the author of this paper feels the need to clarify that the victims of both cases are not criticized here; rather, it is the media's ethics which is at the core of this discussion. It could be argued however, that this 'apology' represents a 'giving in' to the artificial social solidarity created by the media; why 'artificial'? Because it has been imposed this needs to be explained. Criminologists have identified that some types of victims attract greater levels of social empathy: the young antisocial drug addict abused in his childhood and perhaps still sexually exploited in his adulthood, is perceived as a less deserving victim than, let's say, the elderly woman attacked in her home. Indeed, children, women and the elderly have been identified in criminological writings as those victims which society perceive to be 'deserving' of governmental and social protection; these have been labelled as 'ideal victims'. ${ }^{3}$ The victims of the Savile and Ze'evi cases were portrayed, at the time when the stories were aired, as 'ideal'. Indeed, as confirmed by the Operation Yewtree's report on the allegations made on Savile, there were 214 formally recorded sexually related offences, $82 \%$ being on females, many in the 13-16 age groups at the time of the events. ${ }^{13}$ Although significantly lower in the number of allegations, the exposé on Ze'evi reveals five female victims of sexually related offences, possibly between the ages of 18 and 20, where other two victims came forward following the airing of the programme; furthermore, evidence disclosed (but unexplored) in the documentary suggests that the sexual assaults were much more numerous. However, being a victim of crime does not automatically 'transform' the person into an ideal victim; rather, an optimal combination between vulnerability and the ability to resist to the harm is essential in order to find a united social understanding of 'ideal'. Christie ${ }^{3}$ clarifies that this combination will determine the 'socially constructed notions of innocence or blamelessness that conform more closely to an ideal victim'. The construction of the ideal victim, as it differs in time and space, becomes a cultural symbol. Presdee ${ }^{4}$ attributes this construction to the 'political process of the powerful'; however, whilst he discusses this process in relation to 'criminalisation' victimisation too, is shaped by socio-political forces. ${ }^{14}$ The culturalisation of the victim is important, because it is this process, according to Presdee ${ }^{4}$ which 'defines and shapes dominant forms of social life'. This has been the case in the culturalisation of the sexually exploited vulnerable victim in the cases of Savile and Ze'evi. Indeed, reports, critics and news articles commenting on the case of Jimmy Savile are now posing questions such as 'how did Savile get away with it?' ${ }^{15}$ and 'how could this be allowed to happen?'. ${ }^{16}$ According to Barford and Westcott, ${ }^{17}$ 'in an age of criminal records checks and children's rights, it seems almost inconceivable that someone would be allowed such unfettered access'; and yet, this is exactly where the issue lies. In her report, Dame Janet Smith recognises this concern with the following example: In 1969, Savile sexually assaulted $\mathrm{C} 13$ by grabbing her breasts with both hands; he was then rude to her. She told her immediate managers (who were both men and women). The reaction of one of her managers was to show no surprise and to suggest that it would have been more surprising if Savile had not tried to touch her. ${ }^{17}$ Dame Janet Smith's conclusion is that this reaction by the manager was inappropriate 'but one which is not surprising given the culture of the times'. ${ }^{17}$ Indeed, Savile and Ze'evi are being judged by a society whose their cultural tolerances towards those who have experienced sexual assaults of any kind have changed since the 1960s. At the time when the events occurred, sexual offences on children and young women were certainly illegal (Sexual Offences Act 1956); however, the reporting of these was minimal, and in the best of events, if these were reported, many of the cases were dismissed or advised to be dealt with outside the criminal justice system. ${ }^{18}$ In many cases the victim's secrecy was important in order to avoid her stigmatization, ${ }^{19}$ alternatively, such as in the case of the 17 year old nurse at Stoke Mandeville Hospital who was abused by Savile over a period of eighteen months, she asked her mother not to make a fuss because she was scared: 'I was too embarrassed because he was Jimmy Savile. You don't want to get him into trouble. He was Jimmy Savile and I couldn't say a bad word against him' (BBC 2015). Both in the Savile case and in the Ze'evi case, evidence demonstrates that people came to know about these transgressions at the time when they were taking place. Dame Janet Smith's report brings a collection of complaints against Savile, albeit some not officially made, but none dealt with at the time. Moreover, in one of the Top of the Pops broadcast in 1976 all of Britain could witness how Sylvia Edwards, 18 years old, leaped off her chair; the hint was rather explicit when Jimmy Savile followed with the comment, 'I tell you something, a fella could get used to this, as it happens, he really could get used to it'. According to Sylvia, she questioned the legitimacy of Savile's grabbing her back-side, but she was merely dismissed and told 'don't be stupid, this is just Jimmy Savile'. ${ }^{1}$

Similarly, in the exposé on Ze'evi one of the victims (incognito) recalls that after being raped by Ze'evi, she asked to contact the police; however, her family advised her against it, arguing that no one would believe her and that it would ruin her life and theirs. They instructed

\footnotetext{
I "Jimmy Savile Shame: Girl-Molesting Live On 'Top Of The Pops'!”
} 
her to convince herself that 'this has not happened'. Moreover, an Israeli officer interviewed for the documentary (incognito) disclosed that at the time, a number of female soldiers (18-20 years of age) were transferred by him to different military-bases because they complained that Ze'evi attempted to sexually assault them. The officer also noted that those who had been raped would not usually 'run and tell, certainly not in those days'. Indeed, similarly to the socially controversial attitudes towards victims of sexual offences in the UK in the $1960 \mathrm{~s},{ }^{18}$ research in Israel by Elliam has confirmed general stereotypical views and 'blatant expression of contempt for, and humiliation of, victims who approach the legal system'. ${ }^{20}$ This is not to suggest that victims of sexual offences were completely ignored in the 1960s; however, as clearly explained in an academic article written in 1973: unless it could have been proven that the victim was threatened or violence was present and the perpetrator was a stranger, there was little scope for the victim to be taken seriously. ${ }^{19}$ There is no doubt that Savile's and Ze'evi's victims were as deserving in the 1960s as they were in 2016; the difference lies however, in society's recognition of that Moreover, it is about how this cultural recognition has been fuelled that it makes it problematic. It could be argued that it is not so much about a moral social evolvement, as it is, to use Presdee's words ${ }^{4}$ the media's contextualisation of popular knowledge into culture, and its transportation 'into popular consciousness by the public'. The role of the mass media in the neo-liberal state is of great significance in the determination of the culturalisation of the ideal victim. It is argued here that the mass media is not merely a conduit for such culturalisation, rather, the omnipresent $21^{\text {st }}$ century media is responsible for its construction; a genuine social sympathy and solidarity will be used by the media for the further 'staging of good and evil'. ${ }^{21}$ For Presdee ${ }^{4}$ the driving force behind the media is the interconnection between the 'commodification process' and the 'dynamic of the communications market place'. Significantly, according to Green ${ }^{3}$ the ideal victim becomes a type of currency; higher the level of vulnerability and the harm suffered, higher the exchange value. But what this really means? And what are the implications of that? Also, how this process takes place? Finally, what is the role of the media in all of that? In order to answer these questions it is essential to assess the other two factors which according to Green ${ }^{3}$ render the victim a commodity: demand and supply.

\section{Demand}

The 'demand' that Green ${ }^{3}$ refers to, in the process of the commodification of the concept of the ideal victim, is the demand for security. The essential feature which fuels this demand is the 'fear of crime'. Greater the fear of crime is, bigger the demand for protection. Significantly however, this fear of crime has little to do with individual experiences of victimisation. In other words, a person's perception of crime might be affected by a one-off crime experience; this might or might not follow the need to seek protection. However, it is the sense of living in a risk society, as explained by Beck ${ }^{22}$ which, although they may have never been victims of crime, individuals 'will still perceive themselves as being under threat'. Fear from new national and international risks, fear from the unknown and unexplainable maladies, and the struggle of the criminal justice to deal with thesecreate a sense that we are all in this together. This is further enhanced once the knowledge on these events becomes immediate and visual at real time. Indeed, the actual personal harm suffered by a victim is transformed into a social harm; 'harm' which may be merely perceived as a transgression to a common socio-moral sentiment. Thus, the 'ideal victim' becomes an abstract entity, allowing the public to see itself as a victim too. After all, through the World Wide Web we can now call ourselves 'citizens of the world', and we can 'present' our being through the no-borders, no-confinements of internet network communications. In this sense, a risk will be met by a social solidarity, where its terms and conditions have been agreed upon somewhere on the invisible timeless and space-less platform of social media. The term 'public accountability' has been use in this context to illustrate a social process, where the media is joined by citizens in their expressed desire for justice. According to Furedi, ${ }^{7}$ news reporting might 'play an important role in clarifying the moral issues preoccupying society'; whilst the verification process is completed outside of the formal channels of legal and political scrutiny. ${ }^{12}$ Confirming public accountability is further facilitated through blogs and forums which allow free and immediate access and posting of readers' comments; defining this as the work of the 'citizen journalist'. ${ }^{23}$ emphasises the active role that the reader has acquired. Moreover, in this 'space' readers define social conformity while also constructing an understanding of the (in) effectiveness of the criminal justice in general. ${ }^{1}$ An online newspaper which allows for readers' comments is a good example of such an interactive space. The Mail Online, for example, attracted 109 comments for the headline article: 'Savile pictured at the Jersey House of Horrors: Paedophile DJ is surrounded by children at care home where 192 suffered abuse'. ${ }^{24}$ Readers had the facility to either rate up (agree) or rate down (disagree) each of the 109 comments; looking only at the first twenty 'best rated' comments, these have attracted 7345 ratings. The highest rated 'best' comments express a common social and moral solidarity, such as this one: 'All Saville pictures repulse me; goodness only knows how his victims have felt all these years....' ( 737 readers rated this up while 22 readers rated this down). Those thirteen comments with which readers disagreed the most attracted a total of about 4092 readers. The one on the top rated as the 'worst' with 798 rates stated as follows: 'has anything been PROVED??? No...'. An article in The Marker released a few days before the airing of the documentary on Rehavam Ze'evi attracted 2632 Facebook 'shares' and 169 readers' comments on the article. ${ }^{10}$ The comment most highly rated with 75 'likes' and 22 'dislikes' stated: 'it is surprising in the least. The man was coarse. He was a MajorGeneral who made jokes on female soldiers and their legs'. Another reader's comment attracted more than 100 ratings with equal numbers of 'likes' and 'dislikes', stating as follows: 'With all due respect, those who have been quiet for 45 years have lost the right of expression; the man is dead and he cannot defend himself'. Green's 'demand' as an essential feature responsible for the commodification of the victim, could be understood as a demand for justice, albeit a 'populist' one; however, it could be more than that. Some have argued that media watch dogging has brought about greater levels of transparency; some go as far as stressing the importance of mass-media for the healthy functioning of a democratic state. ${ }^{24}$ However, what could be seen as a shared solidarity may in fact be, to borrow Presdee's $s^{4}$ argument, part of the process of the 'commodification of social life', where social relations 'become both a fetish and a commodity'. The submission here is that the 'demand' is demand for 'entertainment', or what Persdee $^{4}$ called 'pleasure', understood as the 'necessary lubricant of everyday consumer life'. Crime as entertainment is not a new concept, and it could be argued that crime fiction allows the reader or viewer to experience a whole range of controversial emotions knowingly that the stories are not real; in the case of 'real life' documentaries however, Scjofield ${ }^{25}$ explains that the crime story is still perceived as entertainment but it is presented as having a social purpose. And this is problematic because of the constructive nature of this reality. The demand for such 'entertainment' responds to what is socially constructed as 'real' and 'outrageous', which is dependent on the 
media's representation of the events. The construction of reality, in this sense, is artificial, not least because what becomes 'transparent' and who is deemed 'accountable' depend on whether and when the media believes it to be newsworthy. This was particularly apparent in the case of Savile. Although the exposé hit the news in late 2012, it was already complete by late 2011 and it was meant to be aired at that Christmas; instead, the documentary was shelved in favour of two Christmas tributes to Savile. ${ }^{26}$ This illustrates the power of the media to choose when to construct and inform the public about a certain reality. Greer \& McLaughlin ${ }^{27}$ argue that this power to choose what is newsworthy and incite the reader to interact with this information is part of the neo-liberal capitalist-centred approach and market competition: good news sells; sensational news sells more- hence the importance of the 'supply'.

\section{Supply}

The vulnerability to harm being the currency (the ideal victim), the fear being the demand (entertainment)- the last factor essential to the commodification of the victim, according to $\mathrm{Green}^{3}$ is the existence of a 'market place', or in other words the supply of the 'goods'. Without demand the marketplace becomes obsolete, hence the need to capitalise on the economic value of the crime and the victim. $^{3}$ To keep the demand flowing, the entertainment supplied should be of great value- indeed, the best of this sort is the scandal. Undoubtedly, sex-related scandals by celebrities stand for excellent entertainment, ${ }^{23}$ particularly if met with 'an institutional culture of impunity', ${ }^{28}$ as it has been argued happened in the Savile case with the BBC and in the Ze'evi case with the Israeli Army. Indeed, it was reported that both these 'national heroes' carried out their sexual transgressions during 'working hours' ${ }^{28,29}$ Moreover, the significance of capitalising on a scandal lies in the social emotions that it is able to evoke. According to Presdee ${ }^{3}$ 'emotionality' is the main feature which 'feeds' our fetishism; hence, scandalising news increases 'profit through a surge in scandalised consumers' ${ }^{28}$ Therefore, greater the scandal- better the news value, and greater the public reaction- better the ratings. Indeed, for the scandalising 'entertainment' to become a profitable news feed, it has to 'elicit a deep cultural unease'. ${ }^{23}$ In turn, the public will alienate themselves from the perpetrators, joining the media in a process of demonization. By doing so, they confirm their own innocence and 'normality', while 'establishing the "otherness" of those who deviate'. ${ }^{23}$ However, this process of the culturalisation of the victim and the demonization of the perpetrator is problematic, not least because the 'scandal' becomes a scandal when the media says so. This can be observed in the case of Savile, where although the scandal was exposed in late 2012, Jimmy Savile's name had already come to the police's attention in 2008. Jersey police's historic abuse investigation at Haut de la Garenne children's home not only uncovered buried skeletons from the house's grounds ${ }^{30}$ but they were faced with allegations by former residents against a number of high profile personalities, one being Savile. However, it appears that at that time there was not enough evidence to support the allegations against Savile. ${ }^{31}$ The Sun made an attempt to capitalise on this event, but it was met by a livid Savile intending to sue the tabloid for inferring connection between him and abuse at the Jersey house: 'I feel as though I have been subjected to a long and drawn out mugging by The Sun newspaper. The only difference is that its journalists do not wear hoodies'. ${ }^{32}$ Moreover, not only the mass media presents the scandal to the public, it also presents its own moral judgment on the event, thus shaping its construct and its value. For example, a few days before the broadcast of Exposed: The Other Side of Jimmy Savile the Independent $t^{33}$ made sure to prepare the readers and viewers of what was to come, with the following headline: 'Paul Gambaccini claims Sir Jimmy Savile used charity work to prevent sexual abuse of schoolchildren being exposed'; this was accompanied by this sub-heading: 'Speaking ahead of a documentary that claims Savile abused schoolgirls, Gambaccini said his former Radio one colleague played tabloid newspapers 'like a Stradivarius' in order to keep the abuse secret'. ${ }^{34}$ The Telegraph went even further, also ahead of the documentary, by suggesting that the liberalism of the 1970s was a conduit for such behaviour: 'The responses of former colleagues of Jimmy Savile to allegations that he sexually abused young girls paints a shocking picture of pop culture in the 1970s'. ${ }^{5}$ Ahead of the screening of the exposé concerning Rehavam Ze'evi however, it appears that the Israeli media was less decisive as to its own view of the events. One of the main national newspapers, Maarive, ${ }^{35}$ initially warned the readers as to this uncertainly by publishing a phone interview which have taken place between one of the documentary's writers and two radio reporters. Although the reporters accused the documentary's team of doing 'shaming after death', ${ }^{36}$ the readers were still able to read the respective defence by the documentary's writer. ${ }^{37}$ The view was clearer however, when Maarive published the following headline: 'Ghandi's widow: "Ghandi was assassinated three times, twice by Ilana Dayan"', the investigative journalist leading the inquiry. ${ }^{38}$ Nevertheless, the tone of the newspaper seemed to change once the documentary was aired. For example, the following headlines appeared almost immediately: 'Ghandi exposé: rape, death of hostages and the risk of soldiers' life' ${ }^{39}$ and 'His legacy is filthy, a racist which should not be memorised' ${ }^{40}$ This adversarial journalism is typical of the neo-liberal market where, according to Greer \& McLaughlin ${ }^{27}$ it fosters 'feeding frenzy' for the commodification of news 'as a mean of economic survival'. Some would argue that this dynamic still has beneficial qualities; for example, Norris refers to the notion of 'democratic public sphere', where mass-media facilitates the 'development of an informed public opinion as an independent check on the power of the state'. ${ }^{41}$ However, this is merely a 'populist justice', where individuals are put on stage in the 'court of public opinion' ${ }^{27}$ In this way, the public enjoys what Presdee ${ }^{3}$ calls 'the blissful state of non-responsibility' of consumption; this eliminates in turn any interest in 'the exploitation and cruelty' that the process of production may involve. This populist justice has been apparent in the increased web traffic related to the Savile and Ze'ev cases. For example, a number of YouTube clips have been uploaded to the web, most aiming at discrediting Jimmy Savile's personality as a cultural icon, with titles such as 'The evil history of Jimmy Savile', ${ }^{42}$ 'Jimmy Savile: audio of an unpleasant encounter'43 and 'Shocking Jimmy Savile jokes from 1992'. ${ }^{2}$ The 'traffic' on Facebook has been even greater for both Savile and Ze'evi; ${ }^{44}$ while there are a couple of Facebook pages with a fair distribution of those pro or against Ze'evi and a total of 662 'likes', those condemning Savile have at least four Facebook pages to express their opinions, with a total of 4166 'likes' or 'followers'. ${ }^{3}$ Significantly, it could be argued that in the case of Ze'evi, the trial by media was given legitimacy by the court of law itself. A request by Ze'evi's wife and son to not allow the airing of

\footnotetext{
${ }^{\text {II }}$ See for example list of a number of clips in this YouTube link https://www. youtube.com/results?search_query=jimmy+savile

III The following Facebook pages have been identified: RIP Sir Jimmy Savile Jimmy Savile's Face on Things

Jimmy Savile Fanclub
} 
the documentary was rejected by a tribunal, ${ }^{45}$ where the judge argued that it was in the public interest to be informed, not least because of public expenditure involved in the memorial enterprises of this public figure. ${ }^{46}$ Similarly, in the case of Savile, the trial by media was given its legitimacy when in early October 2012, the Metropolitan Police Commander, head of the specialist investigation on the Savile case, Peter Spindler, stated in an interview with $B B C$ News that 'at this stage $[\ldots]$ it is quite clear that Savile was a predatory sex offender' ${ }^{, 7}$ In the 2016 documentary however, Spindler admitted that 'he took a risk' 48 by making such an assertion, as apart from victims' statements, there was no substantial evidence to support this claim. Still, reviewing the first media exposé of Savile, Exposed: The Other Side of Jimmy Savile, ${ }^{33}$ Lawson commented that 'the film exercised a hold because of the sense of poetic justice being the instrument of exposure' ${ }^{48}$

\section{Conclusion}

Perhaps media and public reaction in the Savile and Ze'evi cases should be seen as a celebration of victims' empowerment; indeed, the Metropolitan Police Service titled its report into Savile's sexual allegation as 'giving victims a voice'. ${ }^{13}$ Perhaps the trial by media should be seen as some sort of social therapy, as suggested by the following headline in the Telegraph: 'How the Jimmy Savile scandal helped victims to speak out' ${ }^{49}$ And perhaps indeed, the public-media dynamic has promoted a greater cause, a civic duty; as better put by O'Donovan: What was never in doubt was the importance of these victim's stories being heard. Not only by those whose silence conspired - however unintentionally - to hide Savile's crimes for decades. But by all of us, and especially anyone who might still have had any lingering doubts as to the devastating and long-lasting effects of sexual abuse. ${ }^{50}$ However, the submission here is that the media has turned Savile's and Ze'evi's victims into commodities, and highly profitable ones. Drawing upon Green's analysis of the ideal victim, it is argued that Savile's and Ze'evi's victims are a product of a social process rather than a natural consequence of having been harmed. ${ }^{51}$ However, there is no value and certainly no news value if the victim does not come across as vulnerable; the harm has to be visible and the victim needs to be portrayed as if the crime has 'ruined' her life in one way or another. ${ }^{4}$ Indeed, victims interviewed for both exposés disclosed how the sexual harassment, assaults or rapes changed their childhood, their womanhood, their relationships, their view on life, their mental health, their physical health. This however, has been exuberated by the way the documentaries have been edited, where these were able to capture, visually, all those characteristics aiming at encouraging public sympathy: evidence of emotions expressing anger, a sense of vindictiveness, evidence demonstrating that the victims have not moved on and that they were not able to get on with their life as normal- all these accompanied by dramatic music and instructing commentary. Not only have victims acquired a position 'at the heart of the market economy', they have been turned into a product, 'an objective unit to be bought and sold in the market place', where the subjective experience of victimisation becomes irrelevant. ${ }^{3}$ Karin Ward's private autobiography only had two sentences concerning her encounter in her teenage years with a certain 'JS'; however, once the autobiography was downloaded from the internet by the then BBC Newsnight producer Merion Jones (she was not aware that her diary was visible online), it could be argued that Karin Ward and all other victims lost ownership of their experience. Although the victims might have felt a sense of relief in going public, ${ }^{4}$ their presence in the documentary is merely instrumental, they constituted the currency with which the demand for entertainment was supplied. Indeed, the 2016 Savile exposé's narrator opens by saying that 'for decades there was a secret at the heart of British life'; personal lives and personal secrets have turned into a nation's business. Indeed, the greater the emotions, the higher the ratings. But not only the ratings. In fact the media's triumph could not have been greater: ITV's Exposure won three Royal Television Society journalism awards in 2013. The documentary won the 'scoop of the year' and it was named as the 'best home current affairs programme'.52 It could be argued that the role of readers and viewrs in this process resembles what was considered to be the role fulfilled by the English public attending executions during the late $17^{\text {th }}$ century; as observed by Foucault, the whole process of the public execution functioned as a necessary rite for the verification of the offence and its elimination. ${ }^{53}$ However, the difference between the $21^{\text {st }}$ century and the $17^{\text {th }}$ century 'society of the spectacle', ${ }^{54}$ it could be argued, lies in the fact that the $17^{\text {th }}$ century public was merely symbolically confirming or disapproving a decision already taken by the court of law. Although the trial might have been conducted behind closed doors and sometimes resulted in a biased or disproportionate outcome, the trial nevertheless still took place. In the 'spectacle' of the trial by media however, the public 'reclaims justice from the courts' and the offender is 'guilty until proven innocent'. ${ }^{55}$ This dynamic undermines English due process, the rule of law of the right to a fair trial and the principle of innocence until proven guilty. But not only. Significantly, for many citizens the information generated and circulated by the media is the only way they experience and get to know about social problems. Indeed, this construction of knowledge is problematic because it is based on 'immediate and sensationalized impact with little depth of analysis or contextualisation' ${ }^{56}$ In this context the 'empowering nature of the internet' becomes 'tyrannical', where the privacy of others is invaded 'in the name of freedom of expression' ${ }^{57}$ This is emblematic of the neo-liberal market place where the mass media is dependent on the public's greedy consumption. This adverse market place, rather than merely condemning crime and transgression, it transforms it into an entertainment, where violence is mythisised and reproduced through the public involvement in the trial by media dynamic.

\section{Acknowledgments}

None

\section{Conflicts of interest}

The author declares that there is no conflicts of interest.

\section{References}

1. Barak Gregg. Media and crime. In Routledge Handbook of critical criminology. Routledge. 2011

2. Allen Hanry, Savigny Heather. Selling scandals or ideology? The politics of business crime coverage. European Journal of Communication. 2012;27(3):278-290.

IV victims in the Savile expose' said that 'it was like releasing the pressure [...] it felt good, because now everything is out there' and that 'it was a huge release because now you can talk about it without feeling worried about it, without feeling ashamed' ("Abused: The Untold Story"). 
3. Green Simon. Crime, victimisation and vulnerability. Handbook of victims and victimology. 2011;91-117.

4. Presdee Mike. Cultural Criminology and the Carnival of Crime. London and NY: Routledge, 2000.

5. Stanford Peter. Was Jimmy Savile too big a star to challenge? The response of former colleagues of Jimmy Savile to allegations that he sexually abused young girls paints a shocking picture of pop culture in the 1970s. Telegraph. 2012.

6. Jimmy Savile Shame: Girl-Molesting Live On 'Top Of The Pops'.

7. Furedi Frank. Moral Crusades in an Age of Mistrust: The Jimmy Savile Scandal. Palgrave Macmillan. 2013.

8. Rechavam (Gandhi) Ze'evi (1926-2001). Political Biography. Knessetgovil, 2009.

9. Casciani Dominic. The missed chance to get Jimmy Savile. BBC News. 2013.

10. Noiman Efrat. The Uvda documentary: Women claim we have been sexually assaulted by Rehavam Ze'evi. Themaker.com. 2016.

11. Wootliff Raoul. Despite rape claims, state memorial for slain minister goes ahead. The Times of Israel. 2016.

12. Djerf-Pierre Monika, Ekstrom Mats, Johansson Bengt. Policy failure or moral scandal? Political accountability, journalism and new public management. Media, Culture and Society. 2013;35(8):960-976.

13. Gray David, Watt Peter. Giving Victims and Voce. A joint MPS and NSPCC report into allegations of sexual abuse made against Jimmy Savile. 2012

14. Keaton Tony, Godfrey S Barry. Setting the scene: a question of history. Handbook of Victims and Victimology. Routledge. 2011.

15. Sillito David. Analysis: How did Savile get away with it? $B B C$ News 2016.

16. Easton Mark. Savile: 'How could this be allowed to happen?' BBC News. 2015.

17. The Dame Janet Smith Review Report. An independent review into the $B B C$ 's culture and practices during the Jimmy Savile and Stuart hall years. 2016.

18. Harris Jessica, Grace Sharon. A question of evidence? Investigating and prosecuting rape in the 1990s, Home Office Research Study. London: Home Office. 1999.

19. Weis Kurt, Borges S Sandra. Victimology and Rape: The Case of the Legitimate Victim. Issues in Criminology. 1973;8(2):71-115.

20. Paz-Wolk Tzili. Beyond Legislation: Genuine Change in the Interaction between Victims of Sexual Crimes and the Criminal Law System. Israel Law Review. 2015;48(3):357-385.

21. Wemmers Jo-Anne. The meaning of justice for victims, In International Handbook of Victimology. CRC Press. 2010.

22. Becker Howard S. Outsiders. NY: The Free Press, 1963.

23. Jewkes Yvonne. Media and Crime-2015. Barford Vanessa, Westcott Kathryn. Jimmy Savile: The road to hypervigilance. BBC News. 2012.

24. Allen Emily. Savile pictured at the Jersey House of Horrors: Paedophile DJ is surrounded by children at care home where 192 suffered abuse. Mail Online. 2012

25. Scjofield Karin. Collisions n Culture and Crime: Media Commodification of Child Sexual Abuse. In Cultural Criminology Unleashed. Routledge. 2004;121-131.

26. Abused: The Untold Story. BBC. 2016.
27. Greer Chris, McLaughlin. Media justice: Madeleine McCann, intermediatization and 'trial by media' in the English Press. Theoretical Criminology. 2012;16(4):395-416.

28. Greer Chris, McLaughlin Eugene. The Sir Jimmy Savile scandal: Child sexual abuse and institutional denial at the BBC. Crime Media Culture. 2013;9(3):243-263.

29. Oren Amir. Rehavam Ze'evi: the failure of the institution. Haaretz. 2016

30. Child's body found at care home. BBC News. 2008.

31. Fairweather Eileen. Jimmy Savile: He was the tip of the iceberg. Telegraph. 2012.

32. Jimmy Savile turns to Fox Hayes for action against The Sun. The Lawyer 2008.

33. Exposed: The Other Side of Jimmy Savile 3 October 2012. ITV1. 2012

34. Hall John. Paul Gambaccini claims Sir Jimmy Savile used charity work to prevent sexual abuse of schoolchildren being exposed. Independent. 2012 .

35. Surprising phone call to one of Uvda's writers: Ghandi cannot defend himself, he is dead. Maarive News. 2016d.

36. Hughes Gordon. Shamin. In The Sage Dictionary of Criminology.410-411. 2013

37. Gandhi-The true story behind the Myth. 2016c.

38. Ghandi's widow: Ghandi was assassinated three times, twice by Ilana Dayan. Maarive. Culture. 2016.

39. Ghandi exposé: rape, death of hostages and the risk of soldiers' life. Maarive. News. 2016b.

40. Murji Karim. Moral Panic. In The SAGE Dictionary of Criminology. 2013 .

41. His legacy is filthy, racist which should not be memorised. Maarive. News. 2016a.

42. Jimmy Savile is Innocent. Bread \& Batter. 2012.

43. Timeline: Jersey's decades of abuse. BBC News, Jersey. 2014.

44. Tran Mark. Jimmy Savile victims compensation scheme approved by appeal court. Theguardian.com. 2014.

45. Stoke Mandeville nurse: Jimmy Savile took my innocence. $B B C$ News. 2015 .

46. Milovanovic Dragan. Critical perspectives on law. In Routledge Handbook of critical criminology. Routledge. 2011;117-128.

47. Norris Pippa. Public Sentinel: news media and government reform. Washington. 2010.

48. Solove Daniel J. The Future of Reputation: Gossip, Rumour, and Privacy on the Internet. Yale: University Press. 2007.

49. Lawson Mark. Exposure: The Other Side of Jimmy Savile- review. Theguardian.com. 2012

50. O'Donovan Gerard. How the Jimmy Savile scandal helped victims to speak out. The Telegraph. 2016.

51. O'Carroll Lisa. ITV scoops three awards for coverage of Jimmy Savile sex abuse scandal. Theguardian.com. 2013. Berns Nancy. Framing the victim, domestic violence, media and social problems. 2004.

52. Foucault Michel. Discipline and punish: the birth of the prison. 1977.

53. Greer Chris, McLaughlin. Trial by Media: Policing, the 24-7 news media sphere and the politics of outrage. Theoretical Criminology. 2010;15(1), 23-46. 
54. Cepernich Cristopher. Landscapes of Immorality: scandals in the Italian press 1998-2006. Perspectives on European Politics and Society. 2008;9(1):95-109.

55. Critcher C. Moral Panics and the Media. Buckingham: Open University Press. 2003.
56. Cheung AS. Revisiting Privacy and Dignity: Online Shaming in the Global E-Village. Laws. 2014;3(2):301-326.

57. Coronel Sheila S. Corruption and the watchdog role of the news media. In Public Sentinel: news media and government reform. 2010. 